\title{
PREDICTION OF MUTAGENICITY, CARCINOGENICITY, DEVELOPMENTAL TOXICITY, AND SKIN SENSITISATION WITH CAESAR PROGRAM FOR A SET OF CONAZOLES
}

\author{
Mateja BOLČIČ-TAVČAR ${ }^{1}$ and Marjan VRAČKKO ${ }^{2}$ \\ National Institute of Public Health ${ }^{1}$, National Institute of Chemistry², Ljubljana, Slovenia \\ Received in December 2011 \\ CrossChecked in December 2011 \\ Accepted in June 2012
}

\begin{abstract}
This article presents models to predict mutagenicity, carcinogenicity, developmental toxicity, and skin sensitisation for a set of 27 conazoles. The predictions were performed with the program package CAESAR, which is available on the Internet. The CAESAR programs were developed to support the European Community Regulation on chemicals and their safe use (REACH) and follow the OECD principles for (Q)SAR models used for regulatory purposes. The programs provide a number of information, including a binary classification of a compound as toxic or non-toxic and information on similar compounds from the model's training sets (similarity sets). In this study we analysed conazole sets using principal component analysis (PCA). The predictions were compared to the currently valid classification of these substances in the European Union (EU) or to the classification proposed at expert meetings of the Pesticide Risk Assessment and Peer Review (PRAPeR) group. The predicted classification for mutagenicity was in good agreement with regulatory classification, the predictions for carcinogenicity and developmental toxicity showed some discrepancy in particular cases, while the predictions for skin sensitisation showed even greater discrepancy.
\end{abstract}

KEY WORDS: European Chemical Regulation - REACH, Principal Component Analysis, QSAR modelling

Registration of chemicals requires proper risk assessment. It consists of four steps: hazard identification, hazard assessment, exposure assessment, and risk characterisation. Hazard assessment involves determination of toxicological properties of a compound. They are usually determined experimentally applying in vivo or in vitro measurements, which are expensive, time-consuming, and sometimes involve ethical concerns. Computer-assisted (in silico) methods, including Quantitative Structure-Activity/ Property Relationship (QSAR/QSPR) modelling, provide alternative methods for the evaluation of toxicological endpoints. The use of these methods is supported by the European Community Regulation on chemicals and their safe use to protect human health and environment (REACH - Registration, Evaluation, Authorisation and Restriction of Chemical Substances) (1). Beside QSAR/QSPR, REACH acknowledges other in silico methods for read-across and grouping. The REACH Guidance on Information Requirements and Chemical Safety Assessment recommends that all these methods be used in hierarchical (tiered) order (2). Furthermore, the European Chemical Agency (3), a body which implements REACH, advises the industry to use in silico methods (4). An important message is that in their guidelines for $(\mathrm{Q}) \mathrm{SAR}$ models 
REACH, US Environmental Protection Agency (US EPA) and the Organisation for Economic Cooperation and Development (OECD) promote alternative methods to evaluate chemical hazards, both to save animals and to increase information robustness $(5,6)$. QSAR/QSPR modelling rests on the assumption that compounds with "similar molecular structures show similar properties" (7). QSAR models take several steps $(8,9)$. The first is to determine the data set that represents the knowledge base for the model. The data set must contain molecular structures and their specific properties. It is the quality of these data that essentially determines the quality of the model. Structural data should be selected carefully while the property data should be obtained under the same laboratory protocols.

The second step is to determine molecular structures, where different approaches are possible. A molecule can be represented with two-dimensional or three-dimensional structures, which is defined by the positions of all atoms constituting a molecule. In the QSAR/QSPR model the structures are represented with descriptors. Nowadays, a variety of computer software is available to calculate hundreds of descriptors at a time. A common method to select the most relevant descriptors is the genetic algorithm.

The third step involves selection of the modelling method. The most common is multi-dimensional linear regression (MLR), which is very fast, and a result is given in the form of a multi-linear equation. More advanced methods are the principal component analysis (PCA), partial least square, Reach regression, artificial neural networks of different architectures, and learning algorithms. In a standard QSAR model the property is expressed as a continuous variable, as for example dose of activity. Alternatively, the property can be given as affiliation to a particular class of activity. For classification, a variety of methods is available such as linear discriminate analysis, support vector machine, or artificial neural networks of specific architectures.

The last step is the testing and the validation of models. The questions are: how to test a model and how to express the quality of a model. Today, a basic concept is accepted that a model should be tested with an independent test set. An independent test set means a set that was never used in a model-developing procedure. Before modelling starts, a test set is excluded from the compiled data set. Usually, test sets are selected at random from an entire model's pool of data sets. When the model is presented in its final form it is tested with this test set. The quality of a model is usually expressed as the correlation coefficient between predicted and measured values. When a model is used for classification its performance is usually expressed as a ratio between correctly and falsely classified objects. In a binary classification, in which response is either positive or negative, model responses can be true positive (TP), true negative $(\mathrm{TN})$, false positive (FP), or false negative (FN). The models are evaluated for their precision $(\mathrm{P})$, specificity (SP), and sensitivity (SE) using the following formulas: $\mathrm{P}=(\mathrm{TP}+\mathrm{TN}) /(\mathrm{TP}+\mathrm{TN}+\mathrm{FP}+\mathrm{FN}) ; \mathrm{SE}=\mathrm{TP} /$ $(\mathrm{TP}+\mathrm{FN})$; and $\mathrm{SP}=\mathrm{TN} /(\mathrm{TN}+\mathrm{FP})$.

To ensure the transparency of the QSAR/QSPR models used in regulatory procedures, the OECD adopted five principles for their evaluation (10): Principle 1: defined endpoint; Principle 2: unambiguous algorithm; Principle 3: definite applicability domain; Principle 4: measure of goodness-of-fit, robustness and predictivity; and Principle 5: mechanistic interpretation, if possible.

CAESAR programs were developed to support the use of in silico methods in REACH. They provide complex information about the examined structure and the models. In addition to prediction of activity, these include information about applicability that describes how well the examined structure fits in the training set. Our aim was to analyse these results for the entire set of conazoles. The analysis may show some common features in the set which may support the classification pattern of conazoles. The information on applicability should support this classification. Some details are described in Methods. The data set for conazoles is described in the next section.

\section{Data set}

The predictions were performed for a set of 27 conazoles. Conazoles form a group of chemicals which are used in agriculture, in human and veterinary antimycotic therapies, and as non-steroidal anti-oestrogens in the treatment of oestrogen-responsive breast tumours in postmenopausal women. As active substances in plant protection, conazoles marketed in the EU must be tested for mutagenicity, carcinogenicity, developmental toxicity, and skin sensitisation. Conazoles are mostly biologically active substances with known mechanisms of activities. For example, the anti-mycotic activity of conazole fungicides is based on the competitive and reversible inhibition of two cytochrome P450 enzymes, sterol 14 $\alpha$-demethylase and aromatase. These two enzymes are also present 
in mammals, and their inhibition can affect mammalian steroidogenesis (endocrine disruption) (11). Some conazoles like flusilazole inhibit aromatase with an $\mathrm{IC}_{50}$ in the range of cytostatic drugs. Bitertanol, triadimenol, tebuconazole, and propiconazole are weak inhibitors of aromatase (12). Table 1 presents the set of 27 conazoles and their CAESAR classification. Some of the substances are fungicides [bitertanol, bromuconazole, cyproconazole, difenoconazole, diniconazole (-M), epoxiconazole, fenbuconazole, floquiconazole, flusilazole, hexaconazole, ipconazole, metconazole, myclobutanil, penconazole, propiconazole, prothioconazole, tebuconazole, tetraconazole, triadimenol, triticonazole], some are herbicides (amitrole, cafenstrole, epronaz, flupoxam), and some are of unknown biological activity. Metabolite triazole acetic acid, which is sometimes found in plants treated with conazole pesticides, was also added to the list. Data on this set have been reported in references (11-15).

\section{METHODS}

\section{CAESAR models}

CAESAR $(8,16)$ is a project funded by the European Commission dedicated to developing in silico models for the prediction of five endpoints relevant for REACH. These models were developed according to the OECD principles for (Q)SAR models (10) on high quality data sets following the OECD or US EPA standards. To develop the models, different programs for the calculation of molecular descriptors and descriptor selection were used. These models are publicly available over the Internet and with regard to the input, only the SMILES code of molecular structure is required. For bioconcentration, prediction is expressed as a real number and for other four endpoints prediction takes the form of a binary classification. Beside classification, CAESAR provides additional information such a comment, if the descriptors are out of range, and about the similarity set. The similarity set consists of six compounds from the training set, which are the most similar to the evaluated one. Similarity is expressed with the similarity index.

\section{Mutagenicity}

Details of the CAESAR mutagenicity model are given in reference (17). The model is built on a large data set of 4204 compounds with their Ames test results, which were extracted from the original set reported by Kazius et al. (18). For all structures the descriptor pool was calculated using MDL software. BestFirst algorithm from the Waikato Environment for Knowledge Analysis software (WEKA) was applied to select the 27 relevant descriptors. Modelling combines support to vector algorithm and a rule-based system checking for structural alerts. In classification, mutagenicity is expressed as "non-mutagen", "mutagen", or "suspected mutagen".

\section{Carcinogenicity}

Details of the CAESAR carcinogenicity model are given in reference (19). The model was built on a set of 805 non-congeneric compounds extracted from the Carcinogenic Potency Database (CPDBAS). The Hybrid Selection Algorithm developed by BioChemics Consulting SAS (BCX), France was applied to selected eight descriptors from a set of $254 \mathrm{MDL}$ descriptors. Furthermore, a cross correlation matrix, multi-colinearity, and Fisher ratio were applied to 12 descriptors taken from a set of 835 DRAGON descriptors. For classification we used Counter Propagation Artificial Neural Networks. A compound in the training set was classified as non-carcinogenic when mice and rats tested negative, and vice versa, it was classified as carcinogenic when at least one test was positive. The prediction is expressed as "negative" or "positive" together with the class index, which indicates how reliable the prediction is.

\section{Developmental toxicity}

Details of the CAESAR program for developmental toxicity are given in reference (20). The classification model is based on the random forest algorithm. It is built on the Arena data set, which includes 292 compounds (21). In the CAESAR program, the compounds are binarily classified as developmental non-toxicants, if they belong to the FDA categories A or B, or as developmental toxicants, if they belong to the FDA categories $\mathrm{C}, \mathrm{D}$, or $\mathrm{X}$. Descriptors were calculated with DRAGON, T.E.S.T., and MDL programs. Thirteen molecular descriptors were selected using the WEKA software. The testing strategy and test results are given in reference (20). In the prediction, a compound is predicted as "developmental toxicant" or "developmental nontoxicant". 


\section{Skin sensitisation}

Details of the CAESAR model for skin sensitisation are given in reference (22). The data set consists of 209 compounds selected from the Gerberick data set of 211 compounds (23). From a pool of 502 descriptors, which were calculated with DRAGON, the hybrid selection algorithm singled out seven descriptors. The hybrid selection algorithm combines the genetic algorithm with regression technique. The model itself was based on an adaptive fuzzy partition algorithm (24). The prediction is expressed as "active" (for sensitisers) or "inactive" (for non-sensitisers), accompanied by a class index.

\section{Analysis of data}

The predicted classifications for the four endpoints are presented in Table 1. In the further step we analysed the similarity sets, which are given for each prediction. For each endpoint we constructed a representation space for molecules, which combines all similarity sets. In other words, a molecule is represented by a multidimensional binary vector, where each vector component indicates a compound of the similarity set (data available from authors upon request). First, we analysed how many times individual compounds of the training set appeared in the similarity sets. The question was whether a single compound (or several compounds) predominated in the predictions for all conazoles. In the next step, we considered the binary representation vectors as descriptors and implemented principal component analysis (PCA) to explore similarities between compounds. We wanted to see if individual principal axes were predominately composed of active or inactive compounds. We also wanted to see if the principal axes separated the conazoles set in two or more clusters.

The aim of the study was also to predict the toxicological class for the five substances in the conazole set for which no classification at the EU level had been proposed. The predictions for other compounds obtained with the CAESAR models were compared to the EU classification (15) or to the one proposed at Pesticide Risk Assessment and Peer Review (PRAPeR) group meetings (14) where no EU classification was available.

\section{RESULTS}

\section{Mutagenicity}

The predictions are shown in Table 1. Testing showed that predictions for 22 of 27 compounds were true negative, one compound was wrongly predicted as suspected positive, and for four compounds no experimental data were available. Two compounds, climbazole $^{1}$ and omoconazole ${ }^{2}$, appeared in ten similarity sets and econazole ${ }^{3}$ in eight. All three compounds were verified as (tested) non-mutagenic.

The loadings for the PCA were as follows: the first and the second axes combined mofezolac ${ }^{4}$, climbazole ${ }^{1}$, omoconazole $^{2}$, and econazole ${ }^{3}$. The third axis added indolebutyric acid ${ }^{5}$, and haloperidol ${ }^{6}$. All the compounds constituting the first three axes tested non-mutagenic.

The score plots for the first and second axis are shown in Figure 1a. Four clusters are evident; the first consists of 1,2,4-triazole, amitrole, and 1,2,4-triazol acetic acid, the second of epronaz and prothioconazole, the third of ipconazole, myclobutanil, penconazole, cafenstrole, hexaconazole, tetraconazole, metconazole, tebuconazole, triadimenol, and cyproconazole, and the fourth of bitertanol, flusilazole, fenbuconazole, flupoxam, epoxiconazole, and difenoconazole. As almost all compounds were predicted as nonmutagenic, the clusters show only the relationship regarding the similarity sets. Only cafenstrole and epronaz were predicted as mutagenic and epoxiconazole as a suspected mutagen. Epronaz, for which no data on classification is available, was predicted as mutagenic. This prediction was supported by similarity with six compounds in the same set, which all tested mutagenic. On the other hand, the predictions for cafenstrole and epoxiconazole were not supported by similarity sets. The similarity set for cafenstrole was composed of six compounds tested non-mutagenic and for epoxiconazole of four compounds tested nonmutagenic and two mutagenic. The false positive prediction for epoxiconazole was probably due to the presence of epoxide and aziridine groups in the molecule, which were recognised as mutagenic by the program. Diniconazole-M was predicted as nonmutagenic with an equal number of compounds tested mutagenic and non-mutagenic in the similarity set, just like the set for diniconazole. Ipconazole was predicted as non-mutagenic, as all six compounds in its similarity set tested non-mutagenic. The calculated

\footnotetext{
${ }^{1}$ 1-(4-chlorophenoxy)-1-imidazol-1-yl-3,3-dimethylbuxan-2-one

2 1-[1-[2-(4-chlorophenoxy)ethoxy]-1-(2,4-dichlorophenyl)prop-1-en-2yl]imidazole

${ }^{3} 1$-[2-[(4-chlorophenyl)methoxy]-2-(2,4-dichlorophenyl)ethyl]imidazole

${ }^{4}$ 2-[3,4-bis(4-methoxyphenyl)-1,2-oxazol-5-yl]acetic acid

5 4-(1H-indol-3-yl)butanoic acid

${ }^{6}$ 4-[4-(4-chlorophenyl)-4-hydroxypiperidin-1-yl]-1-(4-fluorophenyl)butan-1one
} 
Table 1 CAESAR predictions and comparison with EC regulation for the set of 27 conazoles.

\begin{tabular}{|c|c|c|c|c|c|c|c|c|c|c|}
\hline \multirow[b]{2}{*}{ No } & \multirow[b]{2}{*}{ Substance } & \multirow[b]{2}{*}{ CAS } & \multicolumn{2}{|c|}{ Mutagenicity } & \multicolumn{2}{|c|}{ Carcinogenicity } & \multicolumn{2}{|c|}{ Developmental toxicity } & \multicolumn{2}{|c|}{ Skin sensitisation } \\
\hline & & & CAESAR & $\begin{array}{c}\text { Regulation } \\
\text { or } \\
\text { PRAPeR } \\
\text { proposal } \\
(14,15)\end{array}$ & CAESAR & $\begin{array}{c}\text { Regulation } \\
\text { or PRAPeR } \\
\text { proposal } \\
(14,15)\end{array}$ & CAESAR & $\begin{array}{c}\text { Regulation } \\
\text { or PRAPeR } \\
\text { proposal (14, } \\
15)\end{array}$ & CAESAR & $\begin{array}{c}\text { Regulation } \\
\text { or PRAPeR } \\
\text { proposal } \\
(14,15)\end{array}$ \\
\hline 1 & 1H-1,2,4-triazole ${ }^{1}$ & $288-88-0$ & $\mathrm{~N}$ & $\mathrm{~N}$ & $\mathrm{P}$ & $\mathrm{N}$ & $\begin{array}{l}\mathrm{N} \text { (descriptors } \\
\text { out of range) }\end{array}$ & $\mathrm{P}$ & $\mathrm{P}$ & $\mathrm{N}$ \\
\hline 2 & amitrole $^{2}$ & $61-82-5$ & $\mathrm{~N}$ & $\mathrm{~N}$ & $\mathrm{P}$ & $\mathrm{N}$ & $\mathrm{P}$ & $\mathrm{P}$ & $\mathrm{P}$ & $\mathrm{N}$ \\
\hline 3 & bitertanol $^{3}$ & $55179-31-2$ & $\mathrm{~N}$ & $\mathrm{~N}$ & $\mathrm{~N}$ & $\mathrm{~N}$ & $\mathrm{~N}$ & $\mathrm{P}$ & $\mathrm{P}$ & $\mathrm{N}$ \\
\hline 4 & bromuconazole ${ }^{4}$ & $116255-48-2$ & $\mathrm{~N}$ & $\mathrm{~N}$ & $\mathrm{P}$ & $\mathrm{N}$ & $\mathrm{P}$ & $\mathrm{P}$ & $\mathrm{P}$ & $\mathrm{N}$ \\
\hline 5 & cafenstrole ${ }^{5}$ & $125306-83-4$ & $\mathrm{P}$ & no data & $\mathrm{P}$ & no data & $\mathrm{P}$ & no data & $\mathrm{P}$ & no data \\
\hline 6 & cyproconazole ${ }^{6}$ & $94361-06-5$ & $\mathrm{~N}$ & $\mathrm{~N}$ & $\mathrm{~N}$ & $\mathrm{~N}$ & $\mathrm{P}$ & $\mathrm{P}$ & $\mathrm{P}$ & $\mathrm{N}$ \\
\hline 7 & difenoconazole ${ }^{7}$ & 119446-68-3 & $\mathrm{N}$ & $\mathrm{N}$ & $\mathrm{P}$ & $\mathrm{N}$ & $\mathrm{N}$ & $\mathrm{N}$ & $\mathrm{P}$ & $\mathrm{N}$ \\
\hline 8 & diniconazole $^{8}$ & $76714-88-0$ & $\mathrm{~N}$ & $\mathrm{~N}$ & $\mathrm{~N}$ & $\mathrm{~N}$ & $\mathrm{P}$ & $\mathrm{N}$ & $\mathrm{P}$ & $\mathrm{N}$ \\
\hline 9 & Diniconazole $\mathrm{M}^{9}$ & $83657-18-5$ & $\mathrm{~N}$ & no data & $\mathrm{N}$ & no data & $\mathrm{P}$ & no data & $\mathrm{P}$ & no data \\
\hline 10 & epoxiconazole ${ }^{10}$ & $\begin{array}{l}133855-98-8 \\
\text { or } 106325-08-0\end{array}$ & SP & $\mathrm{N}$ & $P$ & $\mathrm{P}$ & $\mathrm{N}$ & $\mathrm{P}$ & $\mathrm{P}$ & $\mathrm{N}$ \\
\hline 11 & epronaz ${ }^{11}$ & 59026-08-3 & $\mathrm{P}$ & no data & $\mathrm{P}$ & no data & $\mathrm{P}$ & no data & $\mathrm{P}$ & no data \\
\hline 12 & fenbuconazole ${ }^{12}$ & $114369-43-6$ & $\mathrm{~N}$ & $\mathrm{~N}$ & $\mathrm{~N}$ & $\mathrm{~N}$ & $\mathrm{P}$ & $\mathrm{N}$ & $\mathrm{P}$ & $\mathrm{N}$ \\
\hline 13 & fluquinconazole ${ }^{13}$ & $136426-54-5$ & $\mathrm{~N}$ & $\mathrm{~N}$ & $\mathrm{P}$ & $\mathrm{N}$ & $\mathrm{P}$ & $\mathrm{N}$ & $\mathrm{P}$ & $\mathrm{N}$ \\
\hline 14 & flupoxam $^{14}$ & 119126-15-7 & $\mathrm{N}$ & $\mathrm{N}$ & $\mathrm{N}$ & $\mathrm{N}$ & $\mathrm{P}$ & $\mathrm{N}$ & $\mathrm{N}$ & $\mathrm{N}$ \\
\hline 15 & flusilazole $^{15}$ & $85509-19-9$ & $\mathrm{~N}$ & $\mathrm{~N}$ & $\mathrm{P}$ & $\mathrm{P}$ & $\mathrm{N}$ & $\mathrm{P}$ & $\mathrm{P}$ & $\mathrm{N}$ \\
\hline 16 & hexaconazole ${ }^{16}$ & 79983-71-4 & $\mathrm{N}$ & $\mathrm{N}$ & $\mathrm{P}$ & $\mathrm{N}$ & $\mathrm{P}$ & $\mathrm{N}$ & $\mathrm{P}$ & $\mathrm{P}$ \\
\hline 17 & ipconazole $^{17}$ & $125225-28-7$ & $\mathrm{~N}$ & no data & $\mathrm{P}$ & no data & $\mathrm{P}$ & no data & $\mathrm{P}$ & no data \\
\hline 18 & metconazole $^{18}$ & 125116-23-6 & $\mathrm{N}$ & $\mathrm{N}$ & $\mathrm{P}$ & $\mathrm{N}$ & $\mathrm{P}$ & $\mathrm{P}$ & $\mathrm{P}$ & $\mathrm{N}$ \\
\hline 19 & myclobutanil ${ }^{19}$ & $88671-89-0$ & $\mathrm{~N}$ & $\mathrm{~N}$ & $\mathrm{~N}$ & $\mathrm{~N}$ & $\mathrm{P}$ & $\mathrm{P}$ & $\mathrm{P}$ & $\mathrm{N}$ \\
\hline 20 & penconazole ${ }^{20}$ & $66246-88-6$ & $\mathrm{~N}$ & $\mathrm{~N}$ & $\mathrm{~N}$ & $\mathrm{~N}$ & $\mathrm{P}$ & $\mathrm{P}$ & $\mathrm{P}$ & $\mathrm{N}$ \\
\hline 21 & propiconazole ${ }^{21}$ & $60207-90-1$ & $\mathrm{~N}$ & $\mathrm{~N}$ & $\mathrm{P}$ & $\mathrm{N}$ & $\mathrm{P}$ & $\mathrm{N}$ & $\mathrm{P}$ & $\mathrm{P}$ \\
\hline 22 & prothioconazole $^{22}$ & $178928-70-6$ & $\mathrm{~N}$ & $\mathrm{~N}$ & $\mathrm{~N}$ & $\mathrm{~N}$ & $\mathrm{P}$ & $\mathrm{P}$ & $\mathrm{P}$ & $\mathrm{P}$ \\
\hline 23 & tebuconazole ${ }^{23}$ & $107534-96-3$ & $\mathrm{~N}$ & $\mathrm{~N}$ & $\mathrm{~N}$ & $\mathrm{~N}$ & $\mathrm{P}$ & $\mathrm{P}$ & $\mathrm{P}$ & $\mathrm{N}$ \\
\hline 24 & tetraconazole $\mathrm{e}^{24}$ & $112281-77-3$ & $\mathrm{~N}$ & $\mathrm{~N}$ & $\mathrm{P}$ & $\mathrm{N}$ & $\mathrm{P}$ & $\mathrm{N}$ & $\mathrm{N}$ & $\mathrm{N}$ \\
\hline 25 & triadimeno $^{25}$ & 55219-65-3 & $\mathrm{N}$ & $\mathrm{N}$ & $\mathrm{N}$ & $\mathrm{N}$ & $\mathrm{P}$ & $\mathrm{P}$ & $\mathrm{P}$ & $\mathrm{N}$ \\
\hline 26 & $\begin{array}{l}\text { 1,2,4-triazol-1- } \\
\text { acetic acid }\end{array}$ & $28711-29-7$ & $\mathrm{~N}$ & $\mathrm{~N}$ & $\mathrm{~N}$ & no data & $\mathrm{P}$ & no data & $\mathrm{P}$ & no data \\
\hline 27 & triticonazole ${ }^{26}$ & 131983-72-7 & $\mathrm{N}$ & $\mathrm{N}$ & $\mathrm{P}$ & $\mathrm{N}$ & $\mathrm{P}$ & $\mathrm{N}$ & $\mathrm{P}$ & $\mathrm{N}$ \\
\hline
\end{tabular}

$N=$ non-toxic $; P=$ toxic $; S P=$ suspected toxic

${ }^{1} 1 \mathrm{H}-1,2,4-$ triazole

${ }^{2} 1 \mathrm{H}-1,2,4$-triazol-5-amine

${ }^{3}$ 3,3-dimethyl-1-(4-phenylphenoxy)-1-(1,2,4-triazol-1-yl)butan-2-ol

${ }^{4}$ 1-[[4-bromo-2-(2,4-dichlorophenyl)oxolan-2-yl]methyl]-1,2,4-triazole

${ }^{5} \mathrm{~N}, \mathrm{~N}$-diethyl-3-(2,4,6-trimethylphenyl)sulfonyl-1,2,4-triazole-1-carboxamide

${ }^{6}$ 2-(4-chlorophenyl)-3-cyclopropyl-1-(1,2,4-triazol-1-yl)butan-2-ol

71-[[2-[2-chloro-4-(4-chlorophenoxy)phenyl]-4-methyl-1,3-dioxolan-2-yl]methyl]-1,2,4-triazole

${ }^{8}$ 1-(2,4-dichlorophenyl)-4,4-dimethyl-2-(1,2,4-triazol-1-yl)pent-1-en-3-ol

${ }^{9}$ (E,3R)-1-(2,4-dichlorophenyl)-4,4-dimethyl-2-(1,2,4-triazol-1-yl)pent-1-en-3-ol

${ }_{10}^{10} 1$-[[3-(2-chlorophenyl)-2-(4-fluorophenyl)oxiran-2-yl]methyl]-1,2,4-triazole

${ }^{11} \mathrm{~N}$-ethyl-N-propyl-3-propylsulfonyl-1,2,4-triazole-1-carboxamide

${ }^{12}$ 4-(4-chlorophenyl)-2-phenyl-2-(1,2,4-triazol-1-ylmethyl)butanenitrile

${ }_{13}^{3}$ 3-(2,4-dichlorophenyl)-6-fluoro-2-(1,2,4-triazol-1-yl)quinazolin-4-one

${ }^{14} 1$-[4-chloro-3-(2,2,3,3,3-pentafluoropropoxymethyl)phenyl]-5-phenyl-1,2,4-triazole-3-carboxamide

${ }^{15}$ bis(4-fluorophenyl)-methyl-(1,2,4-triazol-1-ylmethyl)silane

${ }^{16}$ 2-(2,4-dichlorophenyl)-1-(1,2,4-triazol-1-yl)hexan-2-ol

${ }_{17}$ 2-[(4-chlorophenyl)methyl]-5-propan-2-yl-1-(1,2,4-triazol-1-ylmethyl)cyclopentan-1-ol

${ }^{18} 5$-[(4-chlorophenyl)methyl]-2,2-dimethyl-1-(1,2,4-triazol-1-ylmethyl)cyclopentan-1-ol

19 2-(4-chlorophenyl)-2-(1,2,4-triazol-1-ylmethyl)hexanenitrile

${ }^{20} 1$-[2-(2,4-dichlorophenyl)pentyl]-1,2,4-triazole

${ }^{21} 1$-[[2-(2,4-dichlorophenyl)-4-propyl-1,3-dioxolan-2-yl]methyl]-1,2,4-triazole

${ }^{22} 2$-[2-(1-chlorocyclopropyl)-3-(2-chlorophenyl)-2-hydroxypropyl]-1H-1,2,4-triazole-3-thione

${ }^{23}$ 1-(4-chlorophenyl)-4,4-dimethyl-3-(1,2,4-triazol-1-ylmethyl)pentan-3-ol

${ }^{24}$ 1-[2-(2,4-dichlorophenyl)-3-(1,1,2,2-tetrafluoroethoxy)propyl]-1,2,4-triazole

${ }^{25}$ 1-(4-chlorophenoxy)-3,3-dimethyl-1-(1,2,4-triazol-1-yl)butan-2-ol

${ }^{26}$ (5E)-5-[(4-chlorophenyl)methylidene]-2,2-dimethyl-1-(1,2,4-triazol-1-ylmethyl)cyclopentan-1-ol 
precision $(\mathrm{P})$ of the model for the analysed set of conazoles was $95.6 \%$, specificity (SP) $95.6 \%$, while sensitivity (SE) could not be calculated because the set did not contain mutagenic compounds.

\section{Carcinogenicity}

Table 1 shows that of the 27 conazoles, 15 were predicted as positive (carcinogenic) and 12 as negative (non-carcinogenic). The loadings show the following: the first axis is a combination of pirinixic acid (tested positive), fluconazole (tested positive), and nefiracetam ${ }^{7}$ (tested negative). The second axis is a combination of bemitradine (tested positive) loxtidine ${ }^{8}$ (tested positive), and pyrazapon ${ }^{9}$ (tested negative), and the third axis is a combination of entramin ${ }^{10}$ (tested positive), formic acid 2-(4-methyl-2thiazolyl)hydrazide ${ }^{11}$ (tested positive), and ionidamine ${ }^{12}$ (tested negative).

The score plot shows five clusters (Figure 1b). Three clusters are dominated by compounds predicted as positive and two clusters by compounds predicted as negative. The clusters of compounds predominately predicted as positive are: 1,2,4-triazole (false positive), amitrole (false positive) and 1,2,4-triazol acetic acid (predicted as negative with no available data), cluster of fluquinconazole (false positive), flupoxam (true negative) and flusilazole (false positive) and cluster of ipconazole (positive with no data), propiconazole (false positive), cyproconazole (true negative), metconazole (false positive), triticonazole (false positive). The first cluster of (mostly) negative compounds consists of hexaconazole (false positive), myclobutanil (true negative), penconazole (true negative), tebuconazole (true negative), and the second one of cafenstrole (predicted as positive with no available data), diniconazole-M (predicted as negative with no available data), diniconazole (true negative), tetraconazole (false positive), and triadimenol (true negative). The model correctly predicted epoxiconazole and flusilazole which are classified as carcinogenic in the Regulation (EC) No. 1272/2008 (15). Three out of five substances, which are not listed in the Regulation (EC) No. 1272/2008 (15) or were not evaluated by PRAPeR group (14) (see Table 1), were predicted as carcinogenic (cafenstrole, epronaz,

\footnotetext{
${ }^{7} \mathrm{~N}$-(2,6-dimethylphenyl)-2-(2-oxopyrrolidin-1-yl)acetamide

${ }^{8}$ [1-methyl-5-[3-[3-(piperidin-1-ylmethyl)phenoxy]propylamino]-1,2,4-triazol3-yl]methanol

9 1-ethyl-3-methyl-8-phenyl-4,6-dihydropyrazolo[4,3-e][1,4]diazepin-5-one

${ }^{10} 5$-nitro-1,3-thiazol-2-amine

${ }^{11} \mathrm{~N}$-[(4-methyl-1,3-thiazol-2-yl)amino]formamide

${ }^{12} 1$-[(2,4-dichlorophenyl)methyl]indazole-3-carboxylic acid
}

ipconazole) and two as non-carcinogenic (diniconazoleM, 1,2,4-triazol acetic acid). Looking at the similarity sets for still unclassified compounds, we can see that a set for cafenstrole, diniconazole-M, and epronaz consists of three compounds tested and predicted as carcinogenic and three as non-carcinogenic. For ipconazole the set consists of two tested and predicted carcinogenic compounds, one correctly predicted non carcinogenic compound, and three carcinogenic substances predicted as non-carcinogenic. The similarity set for 1,2,4-triazol acetic acid is composed of three predicted and tested positive compounds and three compounds predicted negative, but positive. The calculated precision (P) of the model was $54.5 \%$, specificity (SP) $50 \%$, and sensitivity (SE) $100 \%$. Low specificity indicates high number of false positive predictions. On the other hand, sensitivity is very high. This is because only two compounds from the data set (Table 1) were predicted and confirmed as positive (true positive) and no compound was predicted negative and tested positive (false negatives).

\section{Developmental toxicity}

Five conazoles were predicted as developmental non-toxicants and 22 as developmental toxicants. 1,2,4-triazole, a known developmental toxicant, was predicted as non-toxicant with the remark to be "out of descriptors" range. This remark means that the numerical values of one of more descriptors are out of the interval, which is defined by compounds included in the training set. Such a prediction should be evaluated with caution.

Looking at the similarity sets of conazoles in the first cluster, we identified three compounds that appear in all sets: acetazolamide (tested toxicant), allantoin ${ }^{13}$ (tested non-toxicant), and nitrofurazone $\mathrm{e}^{14}$ (tested nontoxicant).

Loadings are the following: the largest part of the first axis includes tolmetin (tested toxicant), chlorpheniramine (tested non-toxicant), and acemetacin ${ }^{15}$ (tested non-toxicant); the second axis includes haloperido ${ }^{16}$ (tested toxicant), triprolidine (tested toxicant), and Spectrum_000171 ${ }^{17}$ (tested toxicant); the third axis includes acetazolamide ${ }^{18}$

\footnotetext{
${ }^{13}$ (2,5-dioxoimidazolidin-4-yl)urea

${ }^{14}$ [(5-nitrofuran-2-yl)methylideneamino]urea

I5 2-[2-[1-(4-chlorobenzoyl)-5-methoxy-2-methylindol-3-yl]acetyl]oxyacetic acid

16 4-[4-(4-chlorophenyl)-4-hydroxypiperidin-1-yl]-1-(4-fluorophenyl)butan-1one

${ }^{17} 2$-[1-(4-methylphenyl)-3-pyrrolidin-1-ylprop-1-enyl]pyridine

${ }^{18} \mathrm{~N}$-(5-sulfamoyl-1,3,4-thiadiazol-2-yl)acetamide
} 


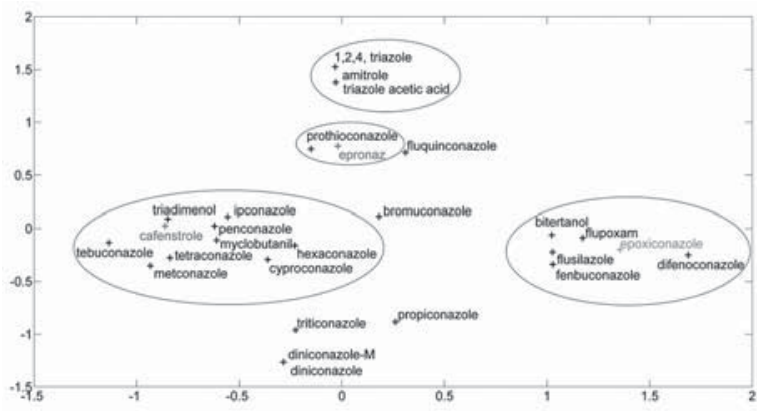

$\mathrm{b}$

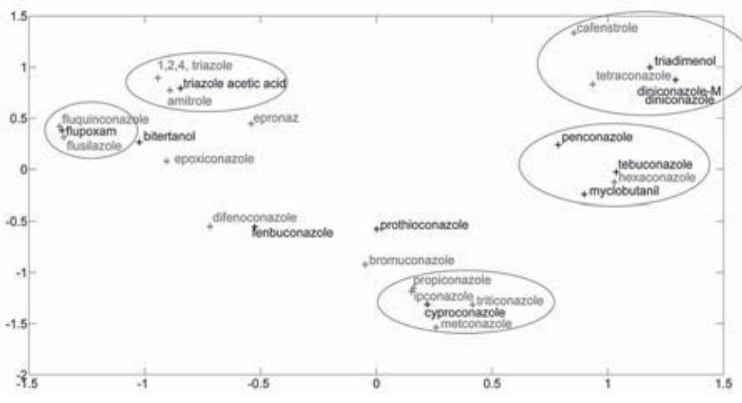

c

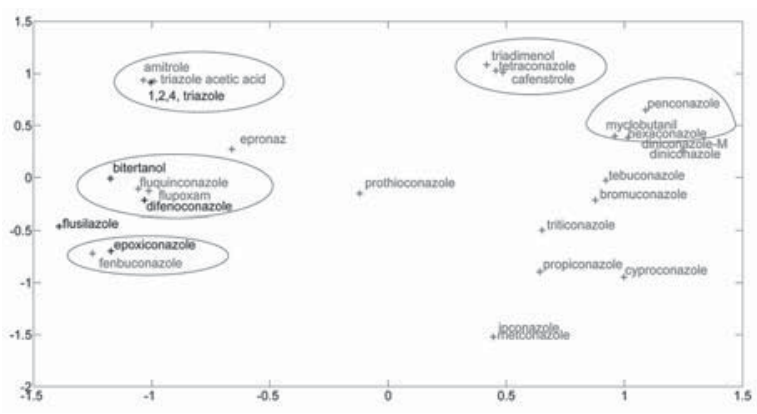

d

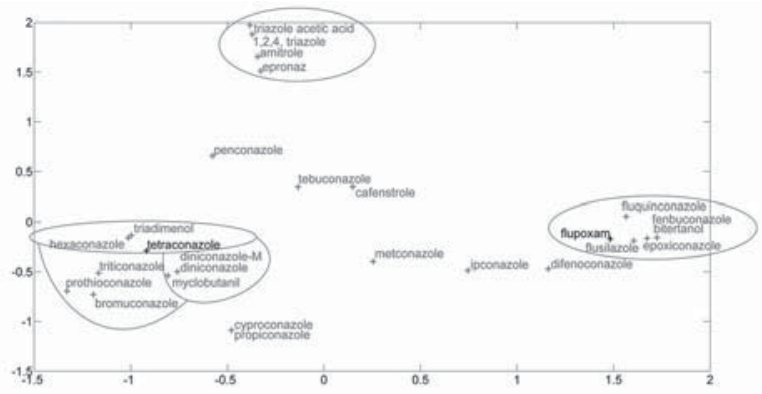

Figure 1 Figures show score plots for mutagenicity (a), carcinogenicity (b), developmental toxicity (c), and skin sensitisation (d). The $x$ and $y$ axes represent the first and the second principal axes, respectively. In all plots, bold indicates toxic, regular non-toxic, and italic suspected toxic compounds. Clusters are indicated with circles. (tested toxicant), allantoin (tested non-toxicant), acemetacin (tested non-toxicant), and nitrofurazone (tested non-toxicant).

In the score plot (Figure 1c) five clusters are evident: the first consists of 1,2,4-triazole (false negative), amitrole (true positive), and 1,2,4-triazol acetic acid (predicted positive with no available data), the second cluster consists of bitertanol (false negative), difenconazole (true negative), fluquinconazole (false positive), and flupoxam (false positive), the third cluster of epoxiconazole (false negative) and fenbuconazole (false positive), the fourth of hexaconazole (false positive) and myclobutanil (true positive), and the fifth cluster of cafenstrole (predicted as positive with available no data), tetraconazole (false positive), and triadimenol (true positive). Amitrole was correctly predicted as a developmental toxicant (true positive). Its similarity set was composed of four correctly predicted developmental non-toxicants and two developmental toxicants. On the other hand, 1,2,4-triazole was wrongly predicted as a developmental non-toxicant (false negative). Cafenstrole, which is in the score plot situated close to both compounds, is predicted as toxicant. Due to different predictions for both neighbours no final conclusion on its toxicity can be made.

Triadimenol and tetraconazole were predicted as developmental toxicants. The predictions were supported by similarity sets, which contain compounds predicted and tested as developmental toxicants.

Ipconazole, diniconazole-M, and epronaz, for which no data are available, were predicted as toxicants. The similarity set for ipconazole is composed of three developmental toxicants and three developmental non-toxicants. Most of these compounds were also found in the similarity set of metconazole, which was correctly predicted as toxicant (true positive). The similarity sets for diniconazole and diniconazole-M, which include five correctly predicted developmental toxicants and two correctly predicted developmental non-toxicants are identical. This is not a surprise taking into consideration that diniconazole$\mathrm{M}$ is the $\mathrm{R}$ isomer of diniconazole. Epronaz was predicted as developmental toxicant with the similarity set composed of four correctly predicted toxicants and two correctly predicted non-toxicants. However, because of dissimilarity between epronaz and the rest of the training set, it is difficult to predict its developmental toxicity. 
The calculated precision $(\mathrm{P})$ of the model for a set of conazoles was $45.5 \%$, specificity (SP) $11.1 \%$, and sensitivity (SE) $69.2 \%$.

\section{Skin sensitisation}

All compounds with the exception of flupoxam and tetraconazole were predicted as active, which means that only these two compounds were not expected to sensitise skin.

The predictions and the analysis of similarity sets show that most conazoles are on the active side of representation space. Only five conazoles were correctly predicted, three of them active and two inactive. Even the right prediction for flupoxam and tetraconazole as inactive was not supported by the similarity sets, where most compounds were predicted and confirmed as active. The correct prediction for prothioconazole (active) should be considered with a caution, because the proposed classification as a skin sensitiser (14) was based on the presence of an impurity in the technical material and not because of the properties of the substance itself. Table 1 shows that in most cases the predictions are in conflict with the classification in the EU Regulation (14), where most of the compounds are classified as inactive. Five conazoles for which no classification is available, were predicted as active. The prediction was supported by the similarity set of six compounds, where active (sensitising) compounds prevailed. Due to the general discrepancy between predictions and measured data, these predictions are less reliable (16). The calculated precision $(\mathrm{P})$ of the model for the set of conazoles was $22.7 \%$, specificity (SP) $10.5 \%$, and sensitivity (SE) $100 \%$

\section{CONCLUSIONS}

This article reports classification of 27 conazoles on four different endpoints. The similarity analysis was performed on four different representation spaces, which were constructed from similarity sets obtained from CAESAR programs. The representation spaces are parts of training sets, i.e., the sets used for developing models and are different for four endpoints. When using the QSAR/QSPR models, the analysis of applicability domain is crucial. An example is the prediction of developmental toxicity for 1,2,4-triazole, which is a known developmental toxicant. The CAESAR prediction is non-toxic with the remark "out of descriptor range". The model for the four endpoints shows clearly different properties. In some cases the predicted and regulatory classification are in accordance, in other cases not. The reason for discrepancies may be that the models were built on limited data sets using structural descriptors. On the other hand, regulatory classification is an extensive procedure, which includes different steps and takes into consideration different facts. Our aim is to promote in silico models to become a part of this procedure. For now, they can be used as a valuable method for setting priorities among chemicals for further testing, but not as standalone methods for classification.

\section{Acknowledgement}

The authors wish to thank the Agency of Research of the Republic of Slovenia (ARRS) for support to our research under contract no. P1-0017.

\section{REFERENCES}

1. EU REACH Regulation Services [displayed 8 November 2011]. Available at http://www.intertek.com/reach/

2. Tsakovska I, Worth A. The use of computational methods for the assessment of chemicals in REACH. Int J BIOautomation 2009;13:151-62.

3. European Chemical Agency (ECHA). Guidance on information requirements and chemical safety assessment [displayed 30 April 2012]. Available at http://echa.europa. eu/guidance-documents/guidance-on-informationrequirements-and-chemical-safety-assessment

4. Benfenati E, Diaza RG, Cassano A, Pardoe S, Gini G, Mays C, Knauf R, Benighaus L. The acceptance of in silico models for REACH: Requirements, barriers, and perspectives. Chem Cent J 2011;5:58-69.

5. Benfenati E, Gini G, Hoffmann S, Luttik R. Comparing in vivo, in vitro and in silico methods and integrated strategies for chemical assessment: Problems and prospects. Altern Lab Anim 2010;38:153-66.

6. Moudgal CJ, Young D, Nichols T, Martin T, Harten P, Venkatapathy R, Stelma G, Siddhanti S, Baier-Anderson C, Wolfe M. Application of QSARs and VFARs to the rapid risk assessment process at US EPA. SAR QSAR Environ Res 2008;19:579-87.

7. Mezey PG, Carbó R, Gironés X. Fundamentals of molecular similarity. New York: Kluwer Academic/ Plenum Publishers; 2001.

8. Benfenati E. The CAESAR project for in silico models for the REACH legislation. Chem Cent J 2010;4(Suppl 1):I1.

9. Benfenati E, Benigni R, Demarini DM, Helma C, Kirkland D, Martin TM, Mazzatorta P, Ouédraogoarras G, Richard AM, Schilter B, Schoonen WGEJ, Snyder RD, Yang C. Predictive models for carcinogenicity and mutagenicity: Frameworks, state-of-the-art, and perspectives. J Environ Sci 
Health C Environ Carcinog Ecotoxicol Rev 2009;27:5790.

10. Organisation for Economic Co-operation and Development Guidance (OECD). Guidance document on the validation of (Q)SAR models. OECD Environment Health and Safety Publications Series on Testing and Assessment No. 6, 2007 [displayed 5 July 2012]. Available at http://www.oecd.org/ officialdocuments/displaydocumentpdf/?cote $=$ env/jm/mono (2007) $2 \&$ doclanguage $=$ en

11. Zarn JA, Brüschweiler BJ, Schlatter JR. Azole fungicides affect mammalian steroidogenesis by inhibiting sterol $14 \alpha-$ demethylase and aromatase. Environ Health Perspect 2003;111:255-61.

12. Trösken ER, Fischer K, Völkel W, Lutz WK. Inhibition of human CYP19 by azoles used as antifungal agents and aromatase inhibitors, using a new LC-MS/MS method for the analysis of estradiol product formation. Toxicology 2006;219:33-40.

13. Bolčič-Tavčar M, Vračko M. Assessing the reproductive toxicity of some (con)azole compounds using StructureActivity Relationship (SAR) approach. SAR QSAR Environ Res 2010;20:711-25.

14. European Food Safety Authority (EFSA). PRAPeR publications [displayed 5 July 2012]. Available at http://www. efsa.europa.eu/en/supporting/pub/174e.htm

15. Regulation (EC) No $1272 / 2008$ of the European Parliament and of the Council of 16 December 2008 on classification, labelling and packaging of substances and mixtures, amending and repealing Directives 67/548/EEC and 1999/45/ EC, and amending Regulation (EC) No 1907/2006 [displayed 5 July 2012]. Available at http://eur-lex.europa.eu/
LexUriServ/LexUriServ.do?uri=OJ:L:2008:353:0001:1355. en:PDF

16. CAESAR project [displayed 8. November 2011]. Available at http://www.caesar-project.eu

17. Ferrari T, Gini G. An open source multistep model to predict mutagenicity from statistical analysis and relevant structural alerts. Chem Centl J 2010;4(Suppl 1):S2.

18. Kazius J, McGuire R, Bursi R. Derivation and validation of toxicophores for mutagenicity prediction. J Med Chem 2005;48:312-20.

19. Fjodorova N, Vračko M, Novič M, Roncaglioni A, Benfenati E. New public QSAR model for carcinogenicity. Chem Cent J 2010;4(Suppl 1):S3.

20. Cassano A, Manganaro A, Martin T, Young D, Piclin N, Pintore M, Bigoni D, Benfenati E. CAESAR models for developmental toxicity. Chem Cent J 2010;4(Suppl 1):S4.

21. Arena VC, Sussman NB, Mazumdar S, Yu S, Macina OT. The utility of Structure-Activity Relationship (SAR) models for prediction and covariate selection in developmental toxicity: comparative analysis of logistic regression and decision tree models. SAR QSAR Environ Res 2004;15:1-18.

22. Chaudhry Q, Piclin N, Cotterill J, Pintore M, Price NR, Cretien JR, Roncaglioni A. Global QSAR models for skin sensitisers for regulatory purposes. Chem Cent J 2010;4(Suppl 1):S5.

23. Gerberick GF, Ryan CA, Kern PS, Schaltter H, Dearman RJ, Kimber I, Patlewicz GY, Basketter DA. Compilation of historical local node data for evaluation of skin sensitization alternative methods. Dermatitis 2005;16:157-202.

24. Bishop CM. Neural Networks for Pattern Recognition. Oxford: Oxford University Press; 1995. 


\section{Izvleček}

\section{NAPOVEDI MUTAGENOSTI, KARCENOGENOSTI, RAZVOJNE TOKSIČNOSTI IN KOŽNE OBČUTLJIVOSTI ZA NIZ KONAZOLOV}

V članku predstavimo modele za napoved mutagenosti, karcenogenosti, razvojne toksičnosti in kožne občutljivosti za niz 27 konazolov. Uporabili smo programski paket CAESAR, ki je dostopen preko interneta. Programi so bili razviti v podporo Evropske Regulacije za varno uporabo kemikaljij REACH in ob upoštevanju OECD principov za validacijo (Q)SAR modelov, ki se uporabljajo za regulatorne namene. Pri napovedi dobimo različne informacije; binarno klasifikacijo kot toksičen ali ne-toksičen in informacijo o šestih najbolj podobnih spojinah iz testnega niza (podobnostni niz). Ti nizi so bili analizirani z metodo glavnih osi (PCA). Napovedi smo primerjali z trenutno veljavnimi klasifikacijami spojin, ki so bile na Evropski komisiji že sprejete, ali pa so predlagane na srečanjih ekspertov (Pesticide Risk Assessment and Peer Review (PRAPeR) group). Napovedane klasifikacije se dobro ujemajo z sprejeto klasifikacijo za mutagenost. Za karcenogenost in razvojno toksičnost se napovedi v nekaterih primerih ujemajo, v nekaterih ne. Pri kožni občutljivosti smo našli več diskrepanc. Za pet spojin, za katere ni eksperimentalnih podatkov smo diskutirali napovedi.

KLJUČNE BESEDE: Evropska Kemijska Regulativa - REACH, metoda glavnih osi, QSAR modeliranje

\section{CORRESPONDING AUTHOR:}

Marjan Vračko

National Institute of Chemistry

Hajdrihova 19, 1000 Ljubljana, Slovenia

E-mail:marjan.vracko@ki.si 